\title{
Performance of strawberry cultivars in mid hill region of Kullu valley of Himachal Pradesh
}

\author{
Jayant Kumar ${ }^{1 *}$, Disha Thakur $^{2}$, Manish Thakur ${ }^{3}$ and Babita ${ }^{4}$ \\ ${ }^{1,2 \& 3}$ Regional Horticultural Research and Training Station, Dr Y,S Parmar University of Horticulture and Forestry , \\ Bajaura, Kullu - 75125 (Himachal Pradesh), INDIA \\ ${ }^{4}$ Department of Fruit Science, Dr Y. S Parmar University of Horticulture and Forestry, Nauni-Solan - 173230 \\ (Himachal Pradesh), INDIA \\ *Corresponding author. E-mail: Jayantkumar_in@yahoo.com
}

Received: September 27, 2015; Revised received: March 12, 2016; Accepted: June 3, 2016

\begin{abstract}
The present study was carried out to evaluate the performance of strawberry cultivars in mid hill region of Kullu valley of Himachal Pradesh. For this purpose nine strawberry cultivars viz Addie, Belrubi, Brighton, Chandler, Dana, Etna, Fern, Pajaro and Selva were planted at spacing of $30 \times 15 \mathrm{~cm}$ in double rows on raised beds of $1 \mathrm{~m} \times$ $3 \mathrm{~m}$ size at Regional Horticultural Research and Training Station, Bajaura, Kullu, Himachal Pradesh. The experiment was laid out in a Randomized block design. The maximum plant height $(16.37 \mathrm{~cm})$ was recorded with cv. Belrubi and maximum plant spread was attained by cV. Fern (EW $23.27 \mathrm{~cm}$ and NS $21.03 \mathrm{~cm}$ ), maximum leaf length $(16.90 \mathrm{~cm})$ was recorded by cv. Belrubi and minimum $(10.00 \mathrm{~cm})$ with cv. Dana. The maximum leaf area was recorded with Chandler $\left(76.03 \mathrm{~cm}^{2}\right)$. The maximum fruit weight $(14.93 \mathrm{gm})$, total soluble solids $\left(12.00^{\circ} \mathrm{B}\right)$, reducing sugars $(5.01 \%)$ and total sugars $(5.44 \%)$ were recorded with $\mathrm{cv}$. Chandler. The maximum fruit yield per plant was observed with $\mathrm{cv}$. Belrubi (996.3g/plant) which was closely followed by cv. Chandler ( $966.7 \mathrm{~g} / \mathrm{plant})$. Thus from the above studies it is concluded that Strawberry cultivars Belrubi and Chandler were best for commercial cultivation in mid hill region of Kullu valley of Himachal Pradesh.
\end{abstract}

Keywords: Chandler, Cultivars, Mid hill, Strawberry

\section{INTRODUCTION}

Strawberry (Fragaria ananasa Duch.) is one of the most attractive and acceptable fruit of the world, which belongs to family Rosaceae and is native of America. Strawberry is delicious fruit and is taken fresh in several ways. It also makes excellent ice cream and Jam on account of its rich aroma and is also good source of vitamin C. It is a soft and a highly perishable fruit, often shipped in frozen condition in western countries. It is preferred by the growers because of its high return per unit area and low cost of cultivation. In India it is cultivated to a limited extent in plains and sub- mountainous areas of Himachal Pradesh, Uttarakhand, Uttar Pradesh, Maharashtra, Karnataka, Punjab, Haryana and Madhya Pradesh. Strawberry is the first fruit to come in the market in the hills. Its cultivation is becoming popular as it is also produced as off season crop in the state. The demand for fresh fruit is also there in the local market due to inflow of tourists during summers. The major problem faced by the growers is the selection of varieties. The cv. Teoga was recommended by Sharma and Badyala (1980) for cultivation in the hills, but now it has shown decline in production Chandel and Badyala (1996). The old varieties are unproductive and have poor keeping quality. Therefore, nine cultivars were introduced from U.S.A and there performance was studied under mid hill region of Kullu valley of Himachal Pradesh.

\section{MATERIALS AND METHODS}

The present study was conducted at Regional Horticultural Research and Training Station, Bajaura, Kullu (HP). The average minimum temperature ranged between 10.5 and $26.4^{\circ} \mathrm{C}$ during the period of study. The healthy and uniform runners of nine cultivars viz., Addie, Belrubi, Brighton, Chandler, Dana, Etna, Fern, Pajaro and Selva were planted at the spacing of $30 \times$ $15 \mathrm{~cm}$ in double row on raised beds of $1 \mathrm{~m} \times 3 \mathrm{~m}$ size. The experiment was laid out in a Randomized block design and plots containing different cultivars were replicated five times. The data on plant growth parameters, fruit yield, fruit size and weight were recorded using standard procedure. The leaf area was recorded by leaf area meter, for taking fruit yield the crop load removed from the plant during the harvesting season was recorded and results were computed in g/ plant. Physical parameters like fruit length $(\mathrm{cm})$ and diameter $(\mathrm{cm})$ were measured with the help of Digital Vernier Calliper. Fruit weight was measured with the help of top pan balance. The unit sample consisted of 
ten fruits and the results were expressed in $\mathrm{cm} /$ fruit for size and $\mathrm{gm} /$ fruit for weight. Chemical attributes includes determination of total soluble sugars were determined with the help of Erma-hand refractometer (0 $32^{0}$ Brix) (AOAC, 1980). The total titratable acidity was calculated on the basis of one $\mathrm{ml} \mathrm{N} / 10 \mathrm{NaOH}$ equivalent to 0.0064 gram of anhydrous citric acid or per cent citric acid in juice. Sugar to acid ratio was calculated by dividing TSS(\%) with titratable acidity (\%).The total sugars were estimated by titrating the boiling mixture of $5 \mathrm{ml}$, each of Fehling A and Fehling $\mathrm{B}$ solution against the hydrolyzed aliquot by using methylene blue as an indicator. Non-reducing sugars were calculated by substracting reducing sugars from the total sugars and multiplying the difference by standard factor i.e. 0.95 and ascorbic acid was determined by AOAC (1980) method.

\section{RESULTS AND DISCUSSION}

The behaviour of all cultivars with relation to growth, fruiting and yield may be attributed to the genetic make up of the cultivar and the soil and climate of the area and environmental conditions prevailing during the growth phase. The evaluation of these cultivars for their relative performance for a particular area may further require investigations and may be refined further. All the varieties started ripening from $24^{\text {th }}$ April except Pajaro, which ripened from $27^{\text {th }}$ April onwards. Etna, Selva and Fern completed their harvest by $17^{\text {th }}$ May, whereas, in other varieties the harvest was completed by $21^{\text {st }}$ May. The maximum plant height was recorded with cv. Belrubi $(16.37 \mathrm{~cm})$ followed by $\mathrm{cv}$. Chandler $(15.83 \mathrm{~cm})$ and Pajaro $(15.33 \mathrm{~cm})$, whereas, minimum plant height was recorded with Selva (10.20 $\mathrm{cm})$. The maximum plant spread (EW and NS) was recorded with cv. Fern $(23.27 \mathrm{~cm}$ and $21.03 \mathrm{~cm})$ followed with cv. Belrubi $(19.60 \mathrm{~cm}$ and $18.47 \mathrm{~cm})$ and the minimum plant spread $(13.60 \mathrm{~cm}$ and $10.80 \mathrm{~cm})$ was recorded with cv. Selva (Table 1).

The maximum leaf length was recorded with cv. Belrubi $(16.90 \mathrm{~cm})$ followed by $\mathrm{cv}$. Chandler $(15.70 \mathrm{~cm})$ and minimum leaf length was recorded with cv. Selva
$(10.80 \mathrm{~cm})$. The maximum leaf area $\left(76.03 \mathrm{~cm}^{2}\right)$, leaf blade length $(6.27 \mathrm{~cm})$ and leaf blade breadth $(5.73$ $\mathrm{cm})$ were recorded with $\mathrm{cv}$. Chandler followed by Belrubi $67.73 \mathrm{~cm}^{2}, 6.20 \mathrm{~cm}$ and $5.27 \mathrm{~cm}$, respectively (Table 1). The minimum leaf area $(37.13 \mathrm{~cm})$, leaf blade length $(4.17 \mathrm{~cm})$ and leaf blade breadth $(3.57$ $\mathrm{cm})$ were recorded with cv. Selva. These significant variation in characters with reference to plant growth can be attributed to the genetic variation of the cultivars and their positive/ negative correlation with soil, climate and prevailing enviornment which may have favoured/ hampered plant growth characteristics (Li et al., 1993). While evaluating the strawberry cultivars under the Mediterranean climate, Dolgun (2006) found Chandler to posess good plant vigour. Rao and Lal (2010) registered cv. Chandler to have a higher number of leaves. Ram et al. (2008), while evaluating strawberry cultivars recorded maximum plant spread in cv. Chandler.

The maximum fruit yield was recorded with cv. Belrubi (996.3g) followed by Chandler (966.7 g) and minimum fruit yield was recorded with Addie (75.23g) (Fig. 1). This might be due to higher plant spread and number of leaves resulting in higher production of photosynthates (Sharma and Badyala, 1980). Singh and Asery (2006) reported yield variation in different cultivars of strawberry due to genetic variation. The results are also in line with findings of Sahu (2013), who recorded Chandler to be the heaviest bearer in terms of yield under mid hill region of North India. The better fruit size and higher number of fruits per plant in cultivar Chandler in the present study may be accounted for higher yield.

The significantly maximum fruit length was recorded with cv. Belrubi $(4.46 \mathrm{~cm})$ followed by cv. Chandler $(3.81 \mathrm{~cm})$ and the minimum with $\mathrm{cv}$. Etna $(43.06 \mathrm{~cm})$ (Table 2). Chandel and Badyala (1996) also observed maximum fruit length with Belrubi under sub tropical zone of the state. Whereas the maximum fruit breadth was observed with cv. Dana $(3.15 \mathrm{~cm})$ followed by Addie $(3.08 \mathrm{~cm})$ and Selva $(3.05 \mathrm{~cm})$. The minimum fruit breadth was observed with cv. Belrubi and Pajaro.

Table 1. Vegetative characteristics of various strawberry cultivars.

\begin{tabular}{|c|c|c|c|c|c|c|c|}
\hline \multirow[b]{2}{*}{ Cultivars } & \multirow{2}{*}{$\begin{array}{l}\text { Plant height } \\
\text { (cm) }\end{array}$} & \multicolumn{2}{|c|}{ Plant spread } & \multirow{2}{*}{$\begin{array}{l}\text { Leaf length } \\
(\mathrm{cm})\end{array}$} & \multirow{2}{*}{$\begin{array}{l}\text { Leaf area } \\
\left(\mathrm{cm}^{2)}\right.\end{array}$} & \multirow{2}{*}{$\begin{array}{l}\text { Leaf Blade } \\
\text { Length }(\mathrm{cm})\end{array}$} & \multirow{2}{*}{$\begin{array}{l}\text { Leaf Blade } \\
\text { Breadth }(\mathrm{cm})\end{array}$} \\
\hline & & $\mathbf{E W} *(\mathrm{~cm})$ & $N S *(\mathrm{~cm})$ & & & & \\
\hline Addie & 13.70 & 17.83 & 13.37 & 14.83 & 55.93 & 5.37 & 4.57 \\
\hline Belrubi & 16.37 & 19.60 & 18.47 & 16.90 & 67.73 & 6.20 & 5.27 \\
\hline Brighton & 14.00 & 18.10 & 16.47 & 14.27 & 59.47 & 5.43 & 4.60 \\
\hline Chandler & 15.83 & 18.77 & 17.00 & 15.70 & 76.03 & 6.27 & 5.73 \\
\hline Dana & 12.33 & 18.13 & 17.10 & 10.00 & 49.83 & 5.50 & 4.47 \\
\hline Etna & 15.13 & 18.27 & 17.13 & 12.27 & 39.93 & 5.40 & 3.77 \\
\hline Fern & 14.37 & 23.27 & 21.03 & 14.50 & 57.63 & 5.07 & 4.30 \\
\hline Pajaro & 15.33 & 19.03 & 18.40 & 11.23 & 53.30 & 5.00 & 4.40 \\
\hline Selva & 10.20 & 17.83 & 13.60 & 10.80 & 37.13 & 4.17 & 3.57 \\
\hline $\mathrm{CD}_{0.05}$ & 1.43 & 2.48 & 2.31 & 0.97 & 6.78 & 0.22 & 0.27 \\
\hline
\end{tabular}

The data presented in the table is two year pooled data; *EW= East-West and NS= North South 
Table 2. Phyisico-chemical characteristics of various strawberry cultivars.

\begin{tabular}{llllllll}
\hline Cultivars & $\begin{array}{l}\text { Fruit } \\
\text { length }(\mathbf{c m})\end{array}$ & $\begin{array}{l}\text { Fruit } \\
\text { breadth }(\mathbf{c m})\end{array}$ & $\begin{array}{l}\text { Fruit weight } \\
\mathbf{( g m )}\end{array}$ & TSS $\left({ }^{\mathbf{o}} \mathbf{B}\right)$ & $\begin{array}{l}\text { Acidity } \\
(\mathbf{\%})\end{array}$ & $\begin{array}{l}\text { Reducing sugars } \\
(\mathbf{\%})\end{array}$ & $\begin{array}{l}\text { Total sugars } \\
(\%)\end{array}$ \\
\hline Addie & 3.58 & 3.08 & 12.67 & 10.57 & 0.86 & 4.25 & 5.12 \\
Belrubi & 4.46 & 2.76 & 12.20 & 10.73 & 0.95 & 4.94 & 5.34 \\
Brighton & 3.75 & 2.85 & 11.53 & 9.90 & 0.80 & 4.52 & 4.91 \\
Chandler & 3.81 & 2.86 & 14.93 & 12.00 & 0.87 & 5.01 & 5.44 \\
Dana & 3.74 & 3.15 & 13.57 & 9.73 & 0.84 & 4.39 & 4.96 \\
Etna & 3.06 & 3.04 & 11.43 & 8.93 & 0.84 & 4.19 & 4.96 \\
Fern & 3.72 & 2.85 & 11.77 & 9.77 & 0.81 & 4.39 & 5.02 \\
Pajaro & 3.29 & 2.76 & 10.10 & 10.70 & 0.56 & 4.17 & 5.05 \\
Selva & 3.80 & 3.05 & 13.37 & 11.43 & 0.80 & 4.82 & 5.12 \\
CD 0.05 & 0.15 & 0.01 & 0.33 & 0.23 & 0.02 & 0.14 & 0.04 \\
\hline
\end{tabular}

The data presented in the table is two year pooled data;

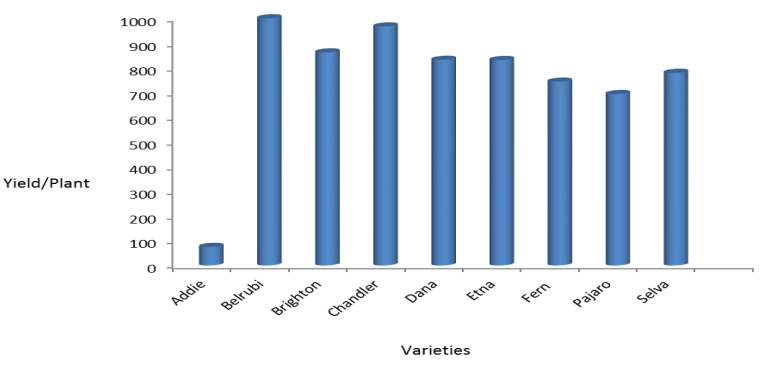

Fig. 1. Diagrammatical representation of yield of various strawberry cultivars.

The cv. Chandler produced the heaviest fruit (14.93g) followed by Dana $(13.57 \mathrm{~g})$. The smallest fruits were recorded with cv. Pajaro (10.10 g). Sahu (2013) also recorded Chandler with highest fruit weight and correlated berries with maximum diameter to have maximum fruit weight and yield. The maximum total soluble solids were recorded with cv. Chandler $(12.00 \%)$ followed by Selva $(11.43 \%)$ and minimum with cv. Dana (9.73\%). The cv. Chandler had maximum reducing sugars $(5.01 \%)$ and total sugars (5.44\%) followed by cv. Belrubi i.e. 4.94 and 5.34 per cent. Belrubi had maximum acidity i.e. 0.95 per cent (Table 2). In the similar studies, Plocharski and Lenartowicz (1974), Singh and Asery (2006) and Dwivedi et al. (2004) reported variation in total soluble solids and acid content in different cultivars. Sistrunk and Moore (1967) found great difference in the quality of 20 strawberry varieties. The factor which may significantly influence the strawberry composition is mineral and organic fertilizer, but this is also dependent upon weather condition. Asrey and Singh (2004), Nagre et al. (2005) and Sharma and Thakur (2008), in their different work on evaluating strawberry cultivars also recorded higher TSS in cv. Chandler. Das et al. (2007) and Kader (1991) in their separate work on evaluating strawberry cultivars recorded highest total sugars and reducing sugar in cv. Chandler. The fruits of Belrubi are not very attractive and they are more acidic. The fruit of cv. Chandler are firm fleshed, juicy and large in size. Thus from the studies it was revealed that cv. Chandler performed well under mid hill zone of Himachal Pradesh both in terms of yield and quality.

\section{Conclusion}

The present study concluded that among different cultivars under evaluation, the maximum fruit weight (14.93gm), total soluble solids $\left(12.00{ }^{\circ} \mathrm{B}\right)$, reducing sugars $(5.01 \%)$ and total sugars $(5.44 \%)$ were recorded with cv. Chandler. The maximum fruit yield per plant was observed with cv. Belrubi (996.3g/plant) but was followed by Chandler ( $966.7 \mathrm{~g} / \mathrm{plant})$. Thus overall the $\mathrm{cv}$. Chandler was found to be the best variety for mid hill zone of the northern India

\section{REFERENCES}

A.O.A.C. (1980). Official method of analysis. Association of analytical chemists, Washington DC, p.366

Asrey, R. and Singh, R. (2004). Evaluation of strawberry varieties under semi-arid irrigated region of Punjab. Ind. J. Hortic., 61 (2): 122-124.

Chandel, J. S. and Badayal S. D. (1996). Performance of some strawberry cultivars in foot hills of Himachal Pradesh. Ann. Agric. Res., 17 (4):375-378.

Das, B., Nath, V., Jana, B.R. and Dey, P. (2007). Performance of strawberry cultivars grown on different mulching materials under sub-humid subtropical plateau conditions of eastern India. Ind. J. Hortic., 64 (2): 136-143.

Dolgun, O. (2006). Yield performance of strawberry plug plants in Eastern Mediterranean climatic conditions. Inter. J. Agric. Res., 1 (3): 280-285.

Dwivedi, S.K., Kareem, A. and Raut, B. (2004). Introduction and evaluation of strawberry cultivars for cold Arid condition of Ladakh. Prog. Hort., 36 (2): 207-210.

Kader, A.A. (1991). Quality and its maintenance in relation to the post-harvest physiology of strawberry. In: Strawberry in 21st Century, pp. 145-152. Dale A and Luby J J (Eds.). Timber Press, Portland, Oregon.

Li ,G.Y., Sui, W. and Ding, X.D. (1993). Comprehensive evaluation of economic characters of some principal cultivars of strawberry. J. Northeast Agric. College, 24: 224-30.

Nagre, P. K., Garad, B. V., Bulbule, A. V. and Patil, V. S. (2005). Varietal performance of strawberry under Igatpuri conditions of Western Ghat Zone. J. Maharashtra Agric. Universities, Coll. Agric., 30 (1): 120-122.

Plocharski, W. and Lenartowicz, W. (1974). Chemical composition of strawberry fruit in relation to individual picking. Fruit Sci. Report, 1: 73-79.

Ram, R. B., Chaturvedi, S. K., Dwivedi, D. H. and Divya, M. 
(2008). Evaluation of some cultivars of strawberry in sodic soil conditions. Ind. J. Hortic., 65 (3): 338-340.

Rao, V.K. and Lal, B. (2010). Evaluation of promising strawberry genotypes under Garhwal Himalayan conditions. Ind. J. Hortic., 67 (4): 470-474.

Sahu, Ankita. (2013). Studies on the comparative performance of strawberry cultivars under mid hill conditions of Himachal Pradesh. Ph.D Theses. Dr Y S Parmar University of Horticulture \& Forestry, Nauni, Solan (HP) $173230.70 \mathrm{p}$.

Sharma, G. and Thakur, M.S. (2008). Evaluation of different strawberry cultivars for yield and quality characters in Himachal Pradesh. Agric. Sci. Digest, 28 (3): 213-215.

Sharma, R.L. and Badyala, S.D. (1980). A study on performance of some strawberry cultivars in the mid hill regions of north India. Prog. Hort., 12 (2): 126- 128.

Singh, R. and Asery, R. (2006). Performance of different strawberry (Fragaria $x$ ananasa Duch) cultivars in south west Punjab. Haryana J. Hort. Sci., 35:32 34.

Sistrunk, W.Q. and Moore, J.N. (1967). Assesment of strawberry quality fresh and frozen. Food Technol. 21:131135. 